\title{
Cardiovascular Complications of Systemic Therapy in Non-Small-Cell Lung Cancer
}

\author{
Magdalena Zaborowska-Szmit ${ }^{1}$, Maciej Krzakowski ${ }^{1}$, Dariusz M. Kowalski ${ }^{1}$ \\ and Sebastian Szmit $2, * \mathbb{D}$ \\ 1 Department of Lung Cancer and Thoracic Tumors, Maria Sklodowska-Curie National Research Institute of \\ Oncology, 02-781 Warsaw, Poland; Magdalena.Zaborowska-Szmit@pib-nio.pl (M.Z.-S.); \\ Maciej.Krzakowski@pib-nio.pl (M.K.); Dariusz.Kowalski@pib-nio.pl (D.M.K.) \\ 2 Department of Pulmonary Circulation, Thromboembolic Diseases and Cardiology, Centre of Postgraduate \\ Medical Education, European Health Centre, 05-400 Otwock, Poland \\ * Correspondence: s.szmit@gmail.com
}

Received: 3 March 2020; Accepted: 24 April 2020; Published: 27 April 2020

check for updates

\begin{abstract}
Cardiovascular diseases may determine therapy outcomes of non-small-cell lung cancer (NSCLC). The evidence for how iatrogenic cardiovascular complications contribute to ceasing anticancer treatment, decreasing the quality of life or even premature death, is unclear. Older patients and smokers are at risk of atherosclerosis and arterial thromboembolic events (TE), such as myocardial infarction or stroke. Venous TE can be observed in up to $15 \%$ of NSCLC patients, but the risk increases three to five times in ALK (anaplastic lymphoma kinase)-rearranged NSCLC. ALK inhibitors are associated with electrophysiological disorders. Cytotoxic agents and anti-VEGF inhibitors mainly cause vascular complications, including venous or arterial TE. Cardiac dysfunction and arrhythmias seem to be less frequent. Chemotherapy is often administered in two-drug regimens. Clinical events can be triggered by different mechanisms. Among epidermal growth factor inhibitors, erlotinib and gefitinib can lead to coronary artery events; however, afatinib and osimertinib can be associated with the development of heart failure. During anti-PD1/anti-PDL1 therapy, myocarditis is possible, which must be differentiated from acute coronary syndrome and heart failure. Awareness of all possible cardiovascular complications in NSCLC encourages vigilance in early diagnostics and treatment.
\end{abstract}

Keywords: cardio-oncology; NSCLC; thromboembolic events; heart failure; acute coronary syndrome; myocarditis; chemotherapy; cardiotoxicity

\section{Introduction}

Lung cancer is a highly heterogeneous disease. From a cardiologist's perspective, it may predispose to thromboembolic complications and often coexists with coronary heart disease and atrial fibrillation [1,2]. From the point of view of an oncologist, it remains one of the main causes of mortality and the prognosis is often comparable or worse than that of advanced heart failure [3].

Modern therapy of lung cancer is typically personalized. Apart from chemotherapy, targeted drugs and immunotherapy are used, and indications for particular types of treatment depend on histologic and molecular diagnosis. The functional state of the patient remains of utmost importance. Concomitant diseases, in particular those of the cardiovascular system, may affect the prognosis and choice of treatment.

The efficacy of lung cancer treatment, in particular non-small-cell lung cancer (NSCLC) has increased, but the question remains as to what extent iatrogenic complications force temporary or premature termination of anticancer treatment, decreasing the quality of life or even causing premature 
death. Publications on thoracic surgery and radiotherapy complications are numerous, but the clinical and prognostic impact of toxicity of systemic therapy in lung cancer is less well researched.

\section{NSCLC and Cardiovascular Diseases}

Available UK data indicates that in patients with lung cancer, irrespective of age and sex, under long term observation there is increased mortality related to the following cardiovascular diseases: pericarditis $(H R=6.71)$, venous thromboembolic disease $(H R=5.05)$, heart failure $(H R=2.14)$, arrhythmias $(H R=1.97)$, peripheral arteries disease $(H R=1.93)$, stroke $(H R=1.78)$, ischemic heart disease $(\mathrm{HR}=1.70)[4]$.

Patients with lung cancer often suffer from concomitant cardiovascular diseases and in the course of antineoplastic treatment may experience various cardiovascular complications (Table 1). Data from an Austrian center in the years 2004-2009 demonstrated that among patients with NSCLC at least one coexisting cardiovascular disease was present in $67.2 \%$ of the population [5]. Cardiovascular (CV) complications were documented in $9.5 \%$ of patients, and the most common were: conduction abnormalities on electrocardiography (28\%), heart failure (19\%), myocardial infarction (19\%), sudden cardiac death (18\%), necessity of coronary revascularization (9\%), pericardial effusion (7\%). The median interval between diagnosis of NSCLC and cardiovascular complication was 13.9 months. Risk factors for CV complications included: advanced age as well as history of atrial fibrillation, myocardial infarction, and heart disease. However, important cardiologic events did not increase mortality (i.e., did not significantly decrease overall survival; OS). Data from the US [6] based on 95,167 patients with NSCLC showed that cardiovascular diseases may increase mortality in patients with stage I-IIIB disease, while there is no difference in survival in patients with stage IV disease. Poor prognosis was connected with concomitant heart failure, myocardial infarction, and cardiac arrhythmias appearing within the observation time; however, the risk differed depending on the stage of disease and type of treatment. For stage I-IIIB patients coexisting CV diseases increased the risk of mortality by 2.59 $(p<0.001)$ for chemotherapy and by $2.20(p<0.001)$ for combined chemo-radiotherapy. 
Table 1. Relationships between cardiovascular events and activity of drugs used in NSCLC.

\begin{tabular}{|c|c|c|c|c|c|c|c|}
\hline & & \multicolumn{3}{|c|}{ Cardiac Toxic Effects } & \multicolumn{3}{|c|}{ Vascular Toxic Effects } \\
\hline & & $\begin{array}{l}\text { Heart Failure/Cardiac } \\
\text { Dysfunction }\end{array}$ & $\begin{array}{c}\text { Atrial Fibrillation/ECG } \\
\text { Changes }\end{array}$ & Myocarditis/Pericarditis & $\begin{array}{c}\text { Venous } \\
\text { Thromboembolism }\end{array}$ & $\begin{array}{l}\text { Acute Coronary } \\
\text { Events }\end{array}$ & Hypertension \\
\hline \multirow{5}{*}{ Cytostatic agents } & Cisplatin & $\uparrow$ in elderly & $\uparrow$ & & $\uparrow \uparrow \uparrow$ & $\uparrow \uparrow \uparrow$ & $\uparrow$ as late effect \\
\hline & Gemcitabine & & $\uparrow \uparrow \uparrow$ & & & $\uparrow \uparrow \uparrow$ & \\
\hline & Vinorelbine & & & & $\begin{array}{l}\uparrow \text { combined with } \\
\text { cisplatin }\end{array}$ & $\uparrow \uparrow \uparrow$ & \\
\hline & Taxanes & & $\uparrow \uparrow \uparrow$ & & & $\uparrow \uparrow \uparrow$ & \\
\hline & Pemetrexed & & & & & $\begin{array}{l}\uparrow \text { in combined } \\
\text { chemotherapy }\end{array}$ & \\
\hline \multirow{4}{*}{ EGFR inhibitors } & Erlotinib & & & & $\uparrow \uparrow \uparrow$ & $\uparrow \uparrow \uparrow$ & \\
\hline & Gefitinib & & & & & $\uparrow$ & \\
\hline & Afatinib & $\uparrow$ & & & & & \\
\hline & Osimertinib & $\uparrow \uparrow \uparrow$ & $\uparrow \uparrow \uparrow$ & & & & \\
\hline \multirow{4}{*}{ ALK inhibitors } & Crizotinib & & $\uparrow \uparrow \uparrow$ & & & & \\
\hline & Ceritinib & & $\uparrow \uparrow \uparrow$ & $\uparrow$ & & & \\
\hline & Alectinib & & $\uparrow$ & & & & \\
\hline & Brigatinib & & & & & & $\uparrow$ \\
\hline \multirow{2}{*}{ VEGF inhibitors } & Bevacizumab & $\uparrow$ & & & $\uparrow \uparrow \uparrow$ & $\uparrow \uparrow \uparrow$ & $\uparrow \uparrow \uparrow$ \\
\hline & Nintedanib & & & & & $\uparrow \uparrow \uparrow$ & $\uparrow \uparrow \uparrow$ \\
\hline \multirow{4}{*}{$\begin{array}{l}\text { Immune } \\
\text { checkpoint } \\
\text { inhibitors }\end{array}$} & Pembrolizumab & \multirow{4}{*}{\multicolumn{2}{|c|}{$\uparrow$ differential diagnosis of reasons is needed }} & & & \multirow{4}{*}{$\uparrow \uparrow \uparrow$} & \\
\hline & Nivolumab & & & $\uparrow \uparrow \uparrow$ & & & \\
\hline & Atezolizumab & & & & & & \\
\hline & Durvalumab & & & & & & \\
\hline
\end{tabular}




\section{Anticancer Drugs and Cardiovascular Complications}

\subsection{Cytotoxic Agents}

Cytotoxic agents used in NSCLC seem to cause primarily vascular complications, including venous or arterial thromboembolic events. Sometimes it is difficult to establish the direct mechanism of vasotoxicity connected with the activity of a particular agent. In many cases, there are coexisting risk factors for atherosclerosis, or present cardiovascular diseases, and the drug seems to be an additional factor for triggering clinical symptoms. Also, chemotherapy is often administered in two-drug regimens which makes it difficult to identify the offending agent responsible for a given clinical event.

\subsubsection{Cisplatin}

Treatment with cisplatin may be associated with coronary artery disease and its symptoms $[7,8]$. Patients on cisplatin treatment show significantly higher risk of myocardial infarction [9]. In patients more than 65 years of age cisplatin-containing chemotherapy may produce significantly higher risk of ischemic heart disease or heart failure. The risk of CV toxicity is highest in patients who received chemo-radiotherapy [10]. Chemotherapy based on cisplatin derivatives permanently damages the endothelium and predisposes to obesity, arterial hypertension, and lipid abnormalities, with subsequent increased risk of atherosclerosis, both in coronary and peripheral blood vessels. In young patients with a good long-term prognosis late complications such as arterial hypertension, left ventricle hypertrophy, ischemic heart disease, and infarctions after 10/20 years from termination of treatment, are common [11].

At the cellular level cisplatin triggers platelet activation and aggregation, increases prothrombotic activity, may lead to endothelial dysfunction, increases the concentration of von Willebrand factor, induces hypomagnesemia and thus constriction of blood vessels, and probably also shows antiangiogenic activity $[12,13]$. Cisplatin may enhance proinflammatory effects and detrimental interactions between endothelial cells, leukocytes, and platelets [14].

Treatment with cisplatin increases the risk of thromboembolic complications [15]. In a retrospective analysis of 932 patients with various types of cancers, the frequency of thromboembolic events related to the use of cisplatin was evaluated between the first dose of chemotherapy and the end of week 4 , after the end of chemotherapy [16]. Complications were noted in $18.1 \%$ patients including peripheral vein thrombosis (49.7\% of events), pulmonary embolism $(25.4 \%)$, peripheral vein thrombosis and pulmonary embolism $(13.6 \%)$, arterial thrombosis $(8.3 \%)$, arterial and venous thrombosis $(3.0 \%)$. It should be noted that $88 \%$ of complications occurred within 100 days from the onset of cisplatin treatment. In unifactorial analysis the following risk factors were identified: gender, age, ethnicity, performance according to Karnofsky scale (KPS), application of drugs stimulating erythropoiesis, presence of venous catheters, site of primary tumor, disease stage, leukocyte count, hemoglobin concentration, results in the Khorana scale. However, in multifactorial analysis the significant factors were only age, KPS, presence of venous catheters, and points in the Khorana scale.

\subsubsection{Gemcitabine}

Treatment with gemcitabine may lead to vascular complications, including thromboembolic complications [17], in particular thrombotic microangiopathy [18]. During gemcitabine treatment episodes of acute ischemia and even necrosis of distal phalanxes of the limbs were noted [19].

Dutch authors analyzed cardiologic safety in patients with NSLC treated with gemcitabine combined with cisplatin, (CG) or epirubicin (EG) [20]. One of the patients receiving EG had myocardial infarction; one patient on CG treatment had atrial fibrillation. A decrease of LVEF $>15 \%$ was observed only in one patient on CG, and 3 patients on EG. There was no correlation between LVEF decrease and total dose of cisplatin, epirubicin and gemcitabine. However, decrease in LVEF in the whole group correlated with a patient's age. Patients with a history of myocardial infarction, aortic valve stenosis, or mitral valve insufficiency had a more significant decrease in LVEF. 
In a phase III study of patients with NSCLC, the efficacy and safety of a regimen of cisplatin with gemcitabine was compared with cisplatin monotherapy [21]. Adding gemcitabine to cisplatin led to a higher efficacy of NSCLC treatment. Cisplatin alone evoked grade 3 heart ischemia in $0.4 \%$ of patients, while $1.5 \%$ of patients treated with cisplatin in combination with gemcitabine were found to have grade 4 heart ischemia. Similarly, arrhythmias of grade 3 occurred only in $0.4 \%$ of patients on cisplatin alone, while in patients receiving cisplatin with gemcitabine grade 3 arrhythmia was noted in $1.6 \%$ of patients, and grade 4 in $1.2 \%$ of patients.

In an interesting phase II study, the efficacy and safety of a regimen containing gemcitabine + pemetrexed + bevacizumab was compared with carboplatin + pemetrexed + bevacizumab [22]. Fatigue and dyspnea were more frequent in patients receiving the regimen with gemcitabine ( $36 \% \mathrm{vs.18 \% )}$, most probably due to induced anemia ( $22 \%$ vs. $7 \%$ ), while thromboembolic events were as frequent $(7 \%)$; in the gemcitabine group there was one death from myocardial infarction.

\subsubsection{Vinorelbine}

Vinca alkaloids may cause autonomic neuropathy [23], coronary artery disease symptoms with altered ECG, including myocardial infarctions [24]. Cardiovascular events associated with vinorelbine use are more common in women [25]. Events characteristic of Prinzmetal angina with typical reversible changes in ECG have also been described, which suggests that ischemia is due to spasms of the coronary vessel.

However, venous complications may be observed. In one report patients with advanced NSCLC (stage IIIB or IV) during the first course of cisplatin and vinorelbine did experience myocardial infarction, as well as pulmonary embolism [26]. In an Italian study, patients treated with vinorelbine and cisplatin more frequently showed venous inflammation than patients treated with gemcytabine and cisplatin [27]. Similarly, Chinese authors observed inflammation of the veins significantly more often in patients receiving vinorelbine with cisplatin, as compared to patients treated with gemcitabine + cisplatin or paclitaxel + cisplatin [28].

\subsubsection{Taxanes}

Paclitaxel and docetaxel may be used in the treatment of NSCLC (first- or second-line). Symptoms of cardiovascular toxicity differed from asymptomatic bradycardia in $\frac{1}{4}$ of patients, compared to severe arrhythmias in selected patients. Both atrial and ventricular arrhythmias are present in about $0.5 \%$ of patients. Cardiac ischemia was also observed, however, rarely. Also, thrombotic events were noted during paclitaxel treatment [29].

Severe arrhythmias may be acute (during drug influx) or subacute (14 days after administration). In a summary of cardiovascular complications grade 4 and 5 according to the National Cancer Institute (NCI) the frequency of the following abnormalities was determined: supraventricular arrhythmias (tachycardia, atrial fibrillation) - $0.24 \%$, ventricular arrhythmias (ventricular tachycardia, ventricular fibrillation) $-0.26 \%$, conduction blocks $-0.11 \%$, cardiac ischemia- $0.29 \%$ [30].

Cardiotoxicity of paclitaxel is probably due to the excessive histamine release. Stimulation of histamine receptors in the heart may lead to increased oxygen requirement by cardiomyocytes, contraction of coronary vessels, and altered chronotropic responses. Stimulation of type 1 histamine receptors may cause elongation of atrioventricular conduction, decrease in the activity of Purkinji fibers, and damage of cardiomyocytes. Moreover, paclitaxel may directly affect Purkinji cells as well as the extra cardiac autonomous nervous system.

Cases of sinus bradycardia were documented, as well as atrioventricular conduction blocks, single ventricular contractions, along with ventricular tachycardia caused by paclitaxel [31]. In a large study of about 1000 patients, cardiotoxicity was seen in $14 \%$, and the most common event was asymptomatic bradycardia (76\%) [32]. According to the literature the frequency of paclitaxel-related bradycardia is $0.1-31 \%$ [33]. 


\subsubsection{Pemetrexed}

Serious cardiovascular events such as myocardial infarction, peripheral edema, cardiac arrhythmias, and transient ischemic attack (TAI) were rarely observed [34]. The results of clinical studies show that these events are usually seen when pemetrexed was used in combination with another cytotoxic drug (cisplatin), and they were present in patients with previously diagnosed risk factors of cardiovascular diseases.

\subsection{Epidermal Growth Factor Receptor Tyrosine Kinase Inhibitors}

Epidermal growth factor (EGF) is a potential chemoattractant and mitogen of a smooth muscle cell in the vessels, its expression is increased in the presence of atherosclerotic lesions or vascular remodeling [35]. EGF induces a proliferation of smooth muscle cells and their ability to synthesize collagen fibers. Blocking the EGF by tyrosine kinase inhibitors (TKIs) may make the surface of atherosclerotic plaque more susceptible to damage. EGF receptors (EGFR), apart from affecting the endothelium, can have a more complex effect on coagulation parameters [36].

\subsubsection{Erlotinib}

Coronary artery events including myocardial infarctions were reported in $2.3 \%$ of patients receiving erlotinib $100 \mathrm{mg} /$ day combined with gemcitabine, compared with $1.2 \%$ in patients receiving gemcitabine alone for pancreatic cancer [37]. Similarly, thromboembolic events in patients treated with erlotinib + gemcitabine were seen in $3.9 \%$, while the frequency was $1.2 \%$ in those receiving gemcitabine alone. Grade 3 or 4 thrombotic complications were present in $11 \%$ of patients receiving erlotinib + gemcitabine, as compared with $9 \%$ in patients on gemcitabine alone.

Int he BeTa study [38] grade 3/4 thromboembolic complications were seen in one patient treated with erlotinib, while in patients receiving erlotinib with bevacizumab, ten grade $3 / 4$ and two grade 5 events were noted. Similarly, arterial hypertension grade $3 / 4$ was diagnosed in four people $(1 \%)$ receiving erlotinib and in fifteen (5\%) receiving erlotinib along with bevacizumab. In both groups one case of pulmonary embolism was diagnosed.

\subsubsection{Gefitinib}

The most probable cardiac complication during gefitinib therapy is acute coronary syndrome (ACS). The risk is due to the reactivity of platelets. Observation analysis based on an examination of 20 aspirin-naïve patients showed that gefitinib may activate platelets via a mechanism connected with ADP [39]. It was demonstrated that gefitinib significantly increases the ability of platelets to produce thromboxane A2 (TXA2), thus increasing the prothrombotic ability [40]. According to another hypothesis, gefitinib directly damages the atherosclerotic plaque. Yamaguchi et al. [41] described a case of a 75-year woman with diabetes and arterial hypertension, treated with gefitinib for lung adenocarcinoma; the ACS occurred 2 months after therapy onset. Lynch et al. [42] described a completely different case-recurrent ACS in a 47-year old man without diabetes or hypertension, a nonsmoker. The first episode occurred after 42 months of gefitinib therapy, and coronary angiography revealed a $95 \%$ constriction of the left anterior descending artery; angioplasty was done with the insertion of a stent covered with everolimus. Two antiplatelet drugs were recommended (aspirin and clopidogrel) and gefitinib therapy was continued. After a month the patient developed dyspnea and atypical chest pain. Upon coronary angiography no significant changes were found, but an analysis of the platelet function was performed. Due to increased concentration of thromboxane, despite aspirin therapy, the dose of clopidogrel increased from $75 \mathrm{mg}$ to $150 \mathrm{mg}$ per day. Following six weeks of gefitinib therapy another ACS occurred, and this time angiography revealed $95 \%$ constriction of the left circumflex artery. Another angioplasty was performed with the insertion of an everolimus-covered stent. Gefitinib was discontinued and within the following two years no coronary events were 
noted. In this patient an increased concentration of thromboxane was found despite aspirin and clopidogrel administration.

\subsubsection{Afatinib}

Afatinibis a non-reversible inhibitor of the ErbB family of receptors(epidermal growth factor receptor-EGFR/ErbB1, human epidermal growth factor receptor 2-HER2/ErbB2, HER4-ErbB4) [43]. Inhibition of the HER2 receptor raised concerns about the cardiological safety of afatinib. Analysis of data from clinical studies, LUX-Lung 3 (229 patients treated with afatinib), LUX-Lung 1 (390 patients treated with afatinib) and 49 other studies (3865 patients treated with afatinib), was designed to determine the risk of heart failure [44]. It appeared that the occurrence of events in clinical randomized studies for 100 patient-years (events/100 patient-years) was similar for afatinib and a placebo (2.40 vs. 2.23), as well as for afatinib and chemotherapy ( $2.28 \mathrm{vs.} 2.92)$; similar frequency was seen in other studies without randomization (2.88). Significant decrease in LVEF was more frequent in the course of chemotherapy compared with afatinib $(13.3 \%$ vs. $6.3 \%$; $p=0.267)$. However, when afatinib was compared with a placebo, the frequency of significant LVEF decrease was similar (4.1\% vs. $4.6 \%)$.

\subsubsection{Osimertinib}

There are comparisons of Osimertinib cardiotoxicity versus other EGFR-TKIs (erlotinib, afatinib, gefitinib) [45]. Retrospective data from 2016-2018 showed that treatment with Osimertinib significantly increases the risk of: QT prolongation, heart failure, and atrial fibrillation. Among the 8450 reported adverse events related to EGFR-TKI 2454 were due to osimertinib, whereas 5836 were associated with other EGFR-TKIs (erlotinib, afatinib, gefitinib). The median time interval until heart failure occurrence was 29 and 23 days, representing significant prolongation of the QT interval.

The problem of prolonged QT was reported in a phase III study aimed at demonstrating the superiority of osimertinib over chemotherapy with pemetrexed and cisplatin/carboplatin [46]. Grade 1 or 2 complications were observed in $4 \%$ of patients, but grade 3 only in one out of 273 patients from the osimertinib group. In this study, one patient, treated with osimertinib, experienced ischemic cerebral stroke. Cardiotoxicity, defined as decrease of LVEF by at least $10 \%$ and below $50 \%$, was noted in $5 \%$ of cases and the median time before complications was 5.5 months.

In clinical studies confirming the superior efficacy of Osimertinib over standard EGFR-TKI (gefitinib or erlotinib), prolonged QT was reported in $10 \%$ of patients on osimertinib ( $2 \%$ grade 3 , below $1 \%$ grade 4 ), compared with $4 \%$ receiving gefitinib/erlotinib (1\% grade 3 ) [47]. In the same study LVEF decrease was noted in $3 \%$ of patients on osimertinib and $1 \%$ of those receiving gefitinib or erlotinib.

Prolonged QT, defined as grade 3, represents a significant clinical problem as it requires therapy discontinuation due to excessive risk of life threatening ventricular tachycardia. In a meta-analysis the percentage of QT prolongation grade 3 cases for Osimertinib therapy was determined to be $2 \%$ [48]. Unfortunately, discontinuation of anti-EGFR therapy may result in rapid progression of cancer [49]. Thus, any decision to with drawosimertinib should be carefully considered, in particular in metastatic disease [50].

The mechanism behind QT prolongation seems to be connected with inhibition of the PI3K pathway, which was demonstrated on animal models [51]. Elongation of QT over 500 msis connected with a significantly higher (2.5 times higher compared to persons with normal QT) risk of serious cardiac arrhythmias. Additional risk factors include electrolyte abnormalities (hypokalaemia), bradycardia, and administration of other drugs which may prolong QT. Family history of sudden cardiac death or congenital long QT syndrome is another factor to consider.

Initial descriptions of heart failure during osimertinib treatment shows that there may be no abnormalities in QT on an ECG. In addition, generalized hypokinesis of the left ventricle and low LVEF, was observed, as well as low volume pericardial effusion, no significant changes on magnetic resonance imaging. In biopsy lymphocyte infiltration and features of edema were found [52]. Another case showed dyspnea, face and limbs edema, and bilateral pleural effusion, along with interstitial 
lung edema on computed tomography [53]. Further diagnosis excluded any inflammatory cause. The authors explained the development of acute heart failure by the fact that Osimertinib inhibits the HER2 receptor [54].

\subsection{ALK Inhibitors}

About $8 \%$ to $15 \%$ of patients with NSCLC may experience venous thromboembolic events (VTE) and certainly chemotherapy increases this risk (as described above). Surprisingly, in a specific molecular subtype of NSCLC such as ALK (anaplastic lymphoma kinase)-rearranged, the incidence of VTE can also be three to five times higher. It was confirmed that $36 \%$ of the patients who had VTE, were younger $(p=0.04)$, had a worse Eastern Cooperative Oncology Group performance status $(p=0.04)$, and higher mortality risk ( $\mathrm{HR}=5.71, p=0.01)$ [55]. A phase II study with the first representatives of targeted therapy (crizotinib) in ROS1-rearranged NSCLC, demonstrated that VTE with different localizations in the venous system can occur at NSCLC diagnosis $(32.1 \%)$ or progression $(35.7 \%)$, as well as during chemotherapy $(17.8 \%)$ or crizotinib treatment $(14.2 \%)$ [56]. To date nobody has confirmed the relationship between a risk of VTE and the activity of ALK inhibitors.

\subsubsection{Crizotinib}

Crizotinibis an inhibitor of ALK and ROS1. In clinical practice two types of ECG complications are observed: bradycardia (heart rate $<60$ beats per minute) and QT prolongation [57]. Bradycardia is caused by the detrimental effect of crizotinib on the activation of HCN4 (hyperpolarization-activated cyclic nucleotide-gated channel 4) in cardiomyocytes [58]. Another cause is a decrease in testosterone concentration [59]. There are other risk factors for bradycardia including, advanced age, poor functional state, and a longer time of crizotinib therapy (bradycardia may appear after many weeks of treatment) [60]. In clinical phase III studies (PROFILE 1007, 1014) the frequency of bradycardia was just over $10 \%$ and in the majority of cases it was mild, asymptomatic, rarely connected with fainting, hypotension, or dizziness [61,62]. However, prolongation of QTcF (Fridericia's formula) $\geq 500 \mathrm{~ms}$ was observed in $2.1 \%$ of patients, and relative prolongation by $\geq 60 \mathrm{~ms}$ in $5 \%$ of cases.

\subsubsection{Ceritinib}

Ceritinibis a selective and strong inhibitor of ALK. ECG abnormalities include bradycardia in $1.9 \%$ of patients and in $6.5 \%$ events connected with prolongation of QTC: grade 3 and $4-0.8 \%$ patients, dose reduction or temporary discontinuation of treatment in $1 \%$ and termination of treatment in $0.2 \%$. A specific cardiovascular complication of ceritinib therapy seems to be pericarditis or pericardial effusion, observed in $5.9 \%$ of patients [63].

\subsubsection{Alectinib}

Alectinibis an inhibitor of tyrosine kinases ALK and RET. In a phase II study the correlation between alectinib concentration and changes in QTcF, was analyzed, as well as the effect of alectinib on heart rates, PR intervals and the duration of QRC. The study did not reveal any clinically significant effect of alectinib on ECG, aside from asymptomatic decrease in the heart rates by 11-13 beats per minute [64].

\subsubsection{Brigatinib}

Brigatinib is an inhibitor of ALK and EGFR. In early phase studies the most common cardiological side effect, grade 3-4, requiring immediate treatment was arterial hypertension (5\%) [65].

\subsection{VEGF Inhibitors}

A complication typical for the whole group of drugs blocking VEGF-dependent pathways is the development of arterial hypertension. The mechanism behind this is thought to be a decrease 
in nitrous oxide synthase and an increase in the activity of PAI-1 (plasminogen activatorinhibitor-1). Some authors suggest a mechanism connected with the activation of the renin-angiotensin-aldosterone system. A mechanism related to lower sodium ions kidney excretion, is also probable. Inhibition of VEGF-dependent pathways leads to the destruction of microcirculation, reduces endothelial growth and possibility inhibits the development of capillary vessels. Decreased density of microcirculation has also been described (the so-called rarefaction). Clinical consequences include increased peripheral vascular resistance and increased arterial blood pressure [66]. However, initially clinical studies in oncology interpreted 150/100 $\mathrm{mmHg}$ as a threshold for arterial hypertension, and not 140/90 $\mathrm{mmHg}$, as in cardiology. This has changed with the introduction of the Common Terminology Criteria for Adverse Events v4.0.

\subsubsection{Bevacizumab}

The most common cardiovascular complication of bevacizumab therapy is arterial hypertension. Initial data suggests a frequency of $35 \%$ in treated patients, out of which $20 \%$ were cases diagnosed de novo, while in $80 \%$ of cases, increased arterial blood pressure was seen in patients with prior hypertension (exacerbation of pre-existing hypertension) [67]. It should be noted that in patients with NSCLC treated with bevacizumab, grade 3 or 4 arterial hypertension occurred with a frequency of $5.7 \%$ (dose $15 \mathrm{mg} / \mathrm{kg}$ ) [68] which is less than in other neoplasms: for example in renal cancer-20.5\% (dose $10 \mathrm{mg} / \mathrm{kg}$ ) [69] or breast cancer-17.9\% (dose $15 \mathrm{mg} / \mathrm{kg}$ ) [70].

In a phase II study, the efficacy of carboplatin alone and paclitaxel with a low dose $(7.5 \mathrm{mg} / \mathrm{kg})$ or high dose $(15 \mathrm{mg} / \mathrm{kg})$ of bevacizumab was compared [71]. Arterial hypertension was diagnosed in 5 out of $32(15.6 \%)$ of those on a low dose of bevacuizumab, 6 out of $35(17.1 \%)$ who received a high dose of bevacizumab, and in 1 out of $32(3 \%)$ on chemotherapy alone. In this study, arterial hypertension did not lead to discontinuation of therapy.

In an ECOG study 4599 patients with non-squamous NSCLC were randomized for treatment with carboplatin and paclitaxel, combined with bevacizumab or not $(15 \mathrm{mg} / \mathrm{kg}$ every 21 days). The prognosis of patients with iatrogenic arterial hypertension diagnosed by the end of first cycle (criterion $>150 / 100 \mathrm{mmHg}$ or increase of diastolic pressure by $20 \mathrm{mmHg}$ ) was compared with the prognosis of patients without hypertension [72]. Patients with iatrogenic hypertension on carboplatin + paclitaxel + bevacizumab compared with normotensive subjects on the same chemotherapy showed significantly longer OS (HR $=0.60 ; p=0.001$ ). Progression-free survival was also significantly longer $(\mathrm{HR}=0.54 ; p<0.0001)$. A comparison between patients on carboplatin + paclitaxel + bevacizumab without hypertension, with patients on chemotherapy alone, showed better OS in the first group $(\mathrm{HR}=0.86 ; p=0.05)$, as well as better progression-free survival ( $\mathrm{HR}=0.72 ; p<0.0001)$. These results suggest that hypertension induced by bevacizumab may be regarded as a positive predictive factor. Because the degree of arterial hypertension can correlate with the dose of bevacizumab [73], some authors suggest beginning bevacizumab therapy with a low dose and then gradually increasing it. Others advocate thorough monitoring of blood pressure along with the rapid onset of hypotensive therapy. Angiotensin converting enzyme inhibitors and calcium channel blockers seem to be effective drugs [74]. Antihypertensive treatment should involve a combination of drugs with various mechanisms of action. Angiotensin converting enzyme inhibitors seem most effective due to beneficial effects on microcirculation and endothelial function [75]. Routine reduction of bevacizumab dose is not recommended as a hypotensive approach, because it may impair the efficacy of antineoplastic treatment.

Another cardiovascular complication of bevacizumab therapy is cardiac dysfunction [76]. The pathomechanism of heart muscle damage is probably due to uncontrolled iatrogenic arterial hypertension and the inhibition of VEGF-dependent pathways. Animal studies revealed that iatrogenic inhibition of VEGF leads to an increase of afterload, decrease of capillary vessels in myocardium, global systolic dysfunction, myocardial fibrosis, and decompensation of circulation [77]. From the clinical point of view the essential observation is that cardiac dysfunction triggered by bevacizumab can potentially resolve spontaneously [78]. In their meta-analysis Choueiri et al. [79] 
analyzed the data of 3784 patients with breast cancer from 1966-2010, including 2366 patients on bevacizumab. The frequency of iatrogenic symptomatic cardiac dysfunction induced by bevacizumab was $1.6 \%$. Relative risk was 4.74 as compared with patients on chemotherapy without bevacizumab $(p=0.001)$. There was no correlation with the dose of bevacizumab or type of additional cytotoxic agents (taxanes vs. capecitabine vs. anthracyclines, $p=0.75$ ). This meta-analysis has limitations, as there are no data on asymptomatic cardiac dysfunction caused by bevacizumab, iatrogenic arterial hypertension, and thromboembolic events, nor on real risk factors of heart failure, nor on the effect of iatrogenic cardiac dysfunction on overall survival. Another problem is the risk of heart failure associated with the advanced age of patients [80].

Thromboembolic events are a serious vascular complication of bevacizumab therapy. In a pooled analysis of 1745 patients with NSCLC or other metastatic carcinoma from 5 randomized studies, the overall occurrence of these events was 3.8\% [81]. The frequency of myocardial infarctions type 1 (resulting from thrombosis/embolus in a coronary artery) was only $1.5 \%$. These complications may appear at any time during therapy; however, available data show that it usually occurs around the third month of treatment. The risk does not seem to be related to a single dose nor a cumulative dose. Being older than 65 years of age and a history of thromboembolic events are the strongest risk factors. The mechanism behind such complications has not been explained; however, it is probably due to the inhibition of VEGF-dependent pathways, as VEGF stimulates the proliferation of endothelial cells, enhances survival of endothelial cells and the integrity of blood vessels [82]. Inhibitors of VEGF such as bevacizumab decrease the regenerative ability of endothelial cells when damaged, and leads to endothelial dysfunction. They also expose collagen from the subendothelial layer, which activates the tissue factor and increases the prothrombotic activity. Additionally, the inhibition of VEGF leads to a decrease in nitric oxide and prostacyclins (vasodilatants), while inducting the erythropoietin production it increases hematocrit and blood viscosity. Interestingly, in the analysis with NSCLC patients in contrast to other types of cancer disease, treatment with bevacizumab did not increase significantly the risk of arterial $(p=0.16)$ and venous adverse events $(p=0.64)$ [83].

Patients with severe thromboembolic events should discontinue bevacizumab therapy. There is no data on the safety of subsequent bevacizumab administration after successful antithrombotic treatment. No evidence of increased risk of bleeding was found in patients on anticoagulants who receive bevacizumab [84].

\subsubsection{Nintedanib}

Nintedanib inhibits three proangiogenic pathways connected with the activity of VEGFR (vascular endothelial growth factor receptors), PDGFR (platelet-derived growth factor receptors), and FGFR (fibroblast growth factor receptors). Apart from the oncological setting, nintedanibis used in idiopathic pulmonary fibrosis. The cardiovascular safety of nintedanib was investigated in clinical studies [85] - serious cardiovascular events were as frequent in nintedanib and in a placebo group, both in patients with and without risk factors for atherosclerosis. The frequency of myocardial infarction increased significantly ( 3.03 per 100 patient-years) in persons with risk factors. Benefits from nintedanib in the second-line treatment of patients with NSCLC were documented in randomized clinical studies, LUME-Lung 1 with docetaxel [86], and LUME-Lung 2 with pemetrexed [87]. Additional analysis showed that arterial hypertension and thromboembolic complications were rare [88]. Thus, unlike other antiangiogenic TKI, nintedanib less frequently produced arterial hypertension and cardiovascular events. Safety evaluation in the LUME-Lung1 study revealed a higher frequency of some adverse events in docetaxel + nintedanib arm compared with docetaxel alone, including: arterial hypertension (3.5\% vs. $0.9 \%)$, bleeding ( $14.1 \%$ vs. $11.6 \%)$, thromboembolic events of all degrees (5.1\% vs. $4.6 \%)$ [89].

\subsection{Immune Checkpoint Inhibitors (ICIs)}

Various adverse events may appear duringanti-PD1/anti-PDL1 treatment as a result of autoimmune reactions and as complications independent from the activity of the immune system [90]. Large clinical 
studies on the efficacy of pembrolizumab, nivolumab and atezolizumabin NSCLC revealed a low risk of cardiovascular events $(<1 \%)$. In clinical studies where pembrolizumab was given in NSCLC in combination with chemotherapy, the risk of cardiac complications did not increase significantly [91,92]. However, when durvalumab was administered after radiochemotherapy in patients with stage III NSCLC, cardiovascular events were seen in $4.4 \%$ of cases [93]. Current FDA data on 21,664 patients from 59 clinical studies suggests that ICI is connected with a higher frequency of myocarditis, vasculitis, ischemic episodes, arrhythmias, and pericardium diseases [94].

The majority of immune complications occur very early, the median time to their occurrence is a maximum of 65 days [95]. Based on the results of 21 early phase studies, serious complications of immunotherapy (including cardiovascular at $2 \%$ ) were several times more frequent during the first four weeks than in subsequent weeks [96]. Late cardiovascular complications have also been described, but according to French data those occurring later than 90 days from immunotherapy onset are typically cases of heart failure with left ventricular systolic dysfunction [97].

In one of the retrospective analyses the risk of serious cardiovascular events in NSCLC such as cardiovascular death, myocardial infarction, stroke, or cardiac insufficiency requiring hospitalization, was evaluated with and without immunotherapy. It revealed the frequency of these complications to be in the range of $13 \%$ (as compared with $10 \%$ in patients receiving other types of therapy) [98]. Clinical characteristics of the group were not related to the risk of serious cardiovascular events. There was no strict algorithm for evaluation of troponin biomarkers and NTproBNP; however, increase of these biomarker concentrations during immunotherapy correlated with the risk of significant cardiovascular events—for troponin it was defined as TnI $>0.01 \mathrm{ng} / \mathrm{mL}(\mathrm{HR}=7.27 ; p<0.001)$ and $\mathrm{BNP}>100 \mathrm{pg} / \mathrm{mL}$ $(\mathrm{HR}=2.65 ; p=0.047)$. In another multicenter study (including patients with NSCLC) increased BNP correlated with the occurrence of cardiomyopathy or arrhythmias during immunotherapy [99]. This finding was confirmed in another study-increased troponin level was a predictor of myocarditis and MACE (major adverse cardiac events), but vascular events were not analyzed [100]. Increased troponin levels in patients with NSCLC should be interpreted with care as it may represent sequelae of previous radiotherapy, chronic heart ischemia in elderly patients with atherosclerosis, or may be caused by non-cardiological factors such as renal dysfunction [101].

One of retrospective observation studies revealed that patients exposed to immune therapy had increased risk of acute vascular complications during first six months of treatment, the risk being twice as high [102]. Atherosclerosis is associated with inflammatory processes and thus immunotherapy may alter its course. In the quoted study from 2015-2018 vascular events during immunotherapy for NSCLC were noted, and among the 1215 patients $2.6 \%$ of them experienced such events, while in lung adenocarcinoma it was 5.2\%. Lung adenocarcinoma, history of vascular events and dyslipidemia were significant risk factors for vascular complications during immunotherapy. Interestingly, in lung adenocarcinoma the frequency of vascular complications was similar for immunotherapy and chemotherapy. However, vascular complications were correlated with a worse prognosis (shorter survival).

The mechanism and clinical significance of pericarditis during immunotherapy is difficult to explain. It seems to be most frequent during nivolumab therapy [103], and may be recurrent [104,105]. The study aimed at determining the frequency of hemodynamically significant pericardial effusion requiring pericardiocentesis, found in a group of 3966 patients on ICIs that the procedure was seldom indicated: during nivolumab treatment $-0.61 \%$, pembrolizumab $-0.19 \%$ andatezolizumab $-0.32 \%$. The survival of patients after pericardiocentesis did not differ between patients on ICIs and those receiving other anticancer drugs [106].

Meta-analyses on the safety of ICIs are now available. In a meta-analysis from 2017 [107] including 22 clinical studies in NSCLC the frequency of cardiopulmonary insufficiency was 1.0\%, cardiac insufficiency-2.0\%, myocardial infarction-1.0\%, stroke-2.0\%. A meta-analysis from 2019 including over 20,000 patients, with various neoplasms on ICIs, showed the risk of cardiovascular complications at $9.8 \%$, mainly heart failure/cardiomyopathy and myocardial infarction [108]. 
A summary of FDA data was presented (the FDA Adverse Events Reports System, FAERS) for the years 2017-2018 [109]. This review was dedicated to all neoplasms and all available ICIs (pembrolizumab, nivolumab, atezolizumab, avelumab, durvalumab, ipilimumab)—it was concluded that many events occurred in patients with lung cancer. In total there were 36,848 reported toxic effects of ICIs and cardiovascular events amounted to $6.2 \%$ and included premature cardiac deaths. Clinical diagnoses comprised: myocarditis $(15 \%)$, atrial fibrillation $(13 \%)$, pericardial diseases, including effusion (13\%), heart failure (17\%) and acute coronary syndromes $(19 \%)$. The highest mortality was seen for myocarditis (50\%), acute coronary syndromes $(43 \%)$ and heart failure $(40 \%)$, slightly less in atrial fibrillation $(22 \%)$ and pericardial complications $(15 \%)$.

\section{Early Diagnosis of Cardiovascular Toxicity in NSCLC}

Treatment of patients with NSCLC may be associated with a risk of serious cardiovascular events. Cardiac dysfunction and arrhythmias seem to be less frequent. During immunotherapy a specific new complication is possible-autoimmune myocarditis, which must be differentiated from acute coronary syndrome and heart failure of another origin [110]. In pericardial effusion it is crucial to exclude neoplastic disease progression, as it will determine the management [111].

Early recognition of all possible iatrogenic cardiovascular events seems to be crucial for optimal treatment (Table 2). Only in this way can premature cardiovascular deaths be avoided. Paradoxically, the simplest diagnosis seems to be in a case of iatrogenic hypertension. Home measurements should be preferred because of the avoidance of the white coat effect, and stress experienced by cancer patients in a hospital or doctor's office. The basis for recognizing arrhythmias is ECG. However, diagnosis of asymptomatic or very rare arrhythmias (e.g., once a week or less) can be troublesome because it requires long-term ECG monitoring. In current daily practice, diagnosis of acute venous or arterial vascular adverse events should be based on the occurrence of clinical symptoms. However, we would like to have markers that would allow us to recognize these acute conditions before the onset of acute symptoms. If we want to recognize myocarditis, frequent assessment of troponin and ECG appears to be the most appropriate method. Finally, for early diagnosis of cardiac dysfunction, echocardiographic monitoring and, above all, strain assessment should be proposed. However, one should be aware that many patients with NSCLC appear after thoracic surgery and radiation therapy. Thus, the quality of echocardiographic imaging may be decreased and cardiac magnetic resonance imaging (MRI) and its strain assessment become an important alternative.

Table 2. Cardiovascular events induced by NSCLC therapy and possible strategy of early diagnosis.

\begin{tabular}{|c|c|c|}
\hline Cardiovascular Event & $\begin{array}{l}\text { Drugs Used in NSCLC and Associated with } \\
\text { Risk of Cardiovascular Events }\end{array}$ & Possible Strategy of Early Diagnosis \\
\hline \multirow{2}{*}{$\begin{array}{l}\text { Heart failure/cardiac } \\
\text { dysfunction }\end{array}$} & $\begin{array}{l}\text { Chemotherapy: Cisplatin } \\
\text { EGFR inhibitors: Afatinib, Osimertinib }\end{array}$ & $\begin{array}{l}\text { Routine echocardiography with repeat left } \\
\text { ventricular ejection fraction (LVEF) measurements as } \\
\text { well as global longitudinal strain (GLS) evaluations. }\end{array}$ \\
\hline & $\begin{array}{l}\text { VEGF inhibitors: Bevacizumab } \\
\text { Immune checkpoint inhibitors }\end{array}$ & $\begin{array}{l}\text { LVEF and strain measurements by magnetic } \\
\text { resonance in patients with reduced quality of } \\
\text { echocardiographic imaging. }\end{array}$ \\
\hline $\begin{array}{l}\text { Atrial fibrillation/ECG } \\
\text { changes }\end{array}$ & $\begin{array}{l}\text { Chemotherapy: Gemcitabine, Taxanes } \\
\text { EGFR inhibitors: Osimertinib } \\
\text { ALK inhibitors: Crizotinib, Ceritinib } \\
\text { Immune checkpoint inhibitors }\end{array}$ & $\begin{array}{l}\text { Routine ECG at each visit } \\
\text { Longterm ECG monitoring in patients with } \\
\text { suspected asymptomatic or rare arrhythmias }\end{array}$ \\
\hline \multirow[b]{2}{*}{ Myocarditis } & ALK inhibitors: Ceritinib & Routine ECG and troponin evaluation at each visit \\
\hline & Immune checkpoint inhibitors & $\begin{array}{l}\text { Cardiac magnetic resonance and myocardial biopsy } \\
\text { at symptoms occurrence }\end{array}$ \\
\hline Venous thromboembolism & $\begin{array}{l}\text { Chemotherapy: Cisplatin, Vinorelbine } \\
\text { EGFR inhibitors: Erlotinib } \\
\text { VEGF inhibitors: Bevacizumab }\end{array}$ & $\begin{array}{l}\text { Computed tomographic pulmonary angiography } \\
\text { and/or compression ultrasonography at symptoms } \\
\text { occurrence }\end{array}$ \\
\hline
\end{tabular}


Table 2. Cont.

\begin{tabular}{|c|c|c|}
\hline Cardiovascular Event & $\begin{array}{l}\text { Drugs Used in NSCLC and Associated with } \\
\text { Risk of Cardiovascular Events }\end{array}$ & Possible Strategy of Early Diagnosis \\
\hline \multirow{4}{*}{ Acute coronary events } & $\begin{array}{l}\text { Chemotherapy: Cisplatin, Gemcitabine, } \\
\text { Vinorelbine, Taxanes }\end{array}$ & \multirow[t]{2}{*}{$\begin{array}{l}\text { Invasive coronary angiography as standard at acute } \\
\text { symptoms occurrence }\end{array}$} \\
\hline & EGFR inhibitors: Erlotinib, Gefitinib & \\
\hline & VEGF inhibitors: Bevacizumab, Nintedanib & \multirow{2}{*}{$\begin{array}{l}\text { Coronary computed tomography angiography as } \\
\text { alternative for selected patients }\end{array}$} \\
\hline & Immune checkpoint inhibitors & \\
\hline \multirow[t]{2}{*}{ Arterial hypertension } & $\begin{array}{l}\text { Chemotherapy: Cisplatin } \\
\text { ALK inhibitors: Brigatinib }\end{array}$ & \multirow{2}{*}{$\begin{array}{l}\text { Home blood pressure measurements } \\
\text { Routine blood pressure control at each visit }\end{array}$} \\
\hline & VEGF inhibitors: Bevacizumab, Nintedanib & \\
\hline
\end{tabular}

\section{Conclusions}

The diversity of cardiovascular complications in NSCLC makes it difficult to plan formal cardiology monitoring. The relatively low frequency of such events instills doubt as to the cost-effectiveness of such monitoring. However, knowledge of these complications leads to vigilance in early diagnostics and treatment, as only such approaches may enhance the benefit resulting from applied anticancer therapy. Clinicians should be watchful for mainly vascular complications and thus preventive strategies should involve optimal control of all potential risk factors.

Unfortunately, current cardio-oncology standards do not concentrate adequately on patients with NSCLC who receive systemic therapy $[112,113]$. The majority of patients with NSCLC are elderly and were smokers in the past. Keeping in mind that most of them suffer from concomitant heart disease, it is crucial to plan further studies with prognostic potential for this specific population of patients.

Author Contributions: S.S. was responsible for design of the manuscript. M.Z.-S. and S.S. drafted the first version of the manuscript. M.K. and D.M.K. reviewed critically. All authors have revised and approved the final published version.

Funding: This research received no external funding.

Conflicts of Interest: M.Z.-S. received speaker's fees and conference support from MSD, Astra Zeneca, Merck, Astellas, Roche, BMS. M.K. declares no conflict of interest. D.M.K. declares: Consultancy and Advisory Board: Roche-Genentech, BMS, MSD, Merck, Pfizer, Boehringer-Ingelheim, Astra Zeneca, TAKEDA. S.S. received speaker's fees from Amgen, Angelini, Bayer, Berlin-Chemie, BMS, Janssen-Cilag, Pfizer, Polpharma, Roche, TEVA.

\section{References}

1. van Herk-Sukel, M.P.; Shantakumar, S.; Penning-van Beest, F.J.; Kamphuisen, P.W.; Majoor, C.J.; Overbeek, L.I.; Herings, R.M. Pulmonary embolism, myocardial infarction, and ischemic stroke in lung cancer patients: Results from a longitudinal study. Lung 2013, 191, 501-509. [CrossRef] [PubMed]

2. Chu, G.; Versteeg, H.H.; Verschoor, A.J.; Trines, S.A.; Hemels, M.E.W.; Ay, C.; Huisman, M.V.; Klok, F.A. Atrial fibrillation and cancer-An unexplored field in cardiovascular oncology. Blood Rev. 2019, 35, 59-67. [CrossRef] [PubMed]

3. Stewart, S.; MacIntyre, K.; Hole, D.J.; Capewell, S.; McMurray, J.J. More 'malignant' than cancer? Five-year survival following a first admission for heart failure. Eur. J. Heart Fail 2001, 3, 315-322. [CrossRef]

4. Strongman, H.; Gadd, S.; Matthews, A.; Mansfield, K.E.; Stanway, S.; Lyon, A.R.; Dos-Santos-Silva, I.; Smeeth, L.; Bhaskaran, K. Medium and long-term risks of specific cardiovascular diseases in survivors of 20 adult cancers: A population-based cohort study using multiple linked UK electronic health records databases. Lancet 2019, 394, 1041-1054. [CrossRef]

5. Kocher, F.; Fiegl, M.; Mian, M.; Hilbe, W. Cardiovascular Comorbidities and Events in NSCLC: Often Underestimated but Worth Considering. Clin. Lung Cancer 2015, 16, 305-312. [CrossRef]

6. Kravchenko, J.; Berry, M.; Arbeev, K.; Lyerly, H.K.; Yashin, A.; Akushevich, I. Cardiovascular comorbidities and survival of lung cancer patients: Medicare data based analysis. Lung Cancer 2015, 88, 85-93. [CrossRef] 
7. Yeh, E.T.; Tong, A.T.; Lenihan, D.J.; Yusuf, S.W.; Swafford, J.; Champion, C.; Durand, J.B.; Gibbs, H.; Zafarmand, A.A.; Ewer, M.S. Cardiovascular complications of cancer therapy: Diagnosis, pathogenesis, and management. Circulation 2004, 109, 3122-3131. [CrossRef]

8. Berliner, S.; Rahima, M.; Sidi, Y.; Teplitsky, Y.; Zohar, Y.; Nussbaum, B.; Pinkhas, J. Acute coronary events following cisplatin-based chemotherapy. Cancer Investig. 1990, 8, 583-586. [CrossRef]

9. van den Belt-Dusebout, A.W.; Nuver, J.; de Wit, R.; Gietema, J.A.; ten Bokkel Huinink, W.W.; Rodrigus, P.T.; Schimmel, E.C.; Aleman, B.M.; van Leeuwen, F.E. Long-term risk of cardiovascular disease in 5-year survivors of testicular cancer. J. Clin. Oncol. 2006, 24, 467-475. [CrossRef]

10. Steingart, R.M.; Yadav, N.; Manrique, C.; Carver, J.R.; Liu, J. Cancer survivorship: Cardiotoxic therapy in the adult cancer patient; cardiac outcomes with recommendations for patient management. Semin. Oncol. 2013, 40, 690-708. [CrossRef]

11. Meinardi, M.T.; Gietema, J.A.; van der Graaf, W.T.; van Veldhuisen, D.J.; Runne, M.A.; Sluiter, W.J.; de Vries, E.G.; Willemse, P.B.; Mulder, N.H.; van den Berg, M.P.; et al. Cardiovascular morbidity in long-term survivors of metastatic testicular cancer. J. Clin. Oncol. 2000, 18, 1725-1732. [CrossRef] [PubMed]

12. Icli, F.; Karaoguz, H.; Dincol, D.; Demirkazik, A.; Günel, N.; Karaoğuz, R.; Uner, A. Severe vascular toxicity associated with cisplatin-based chemotherapy. Cancer 1993, 72, 587-593. [CrossRef]

13. Miller, K.D.; Sweeney, C.J.; Sledge, G.W., Jr. Redefining the target: Chemotherapeutics as antiangiogenics. J. Clin. Oncol. 2001, 19, 1195-1206. [CrossRef] [PubMed]

14. Alena, R.; Perik, P.J.; van Veldhuisen, D.J.; de Vries, E.G.; Gietema, J.A. Cardiovascular toxicity caused by cancer treatment: Strategies for early detection. Lancet Oncol. 2009, 10, 391-399. [CrossRef]

15. Yeh, E.T.; Bickford, C.L. Cardiovascular complications of cancer therapy: Incidence, pathogenesis, diagnosis, and management. J. Am. Coll. Cardiol. 2009, 53, 2231-2247. [CrossRef]

16. Moore, R.A.; Adel, N.; Riedel, E.; Bhutani, M.; Feldman, D.R.; Tabbara, N.E.; Soff, G.; Parameswaran, R.; Hassoun, H. High incidence of thromboembolic events in patients treated with cisplatin-based chemotherapy: A large retrospective analysis. J. Clin. Oncol. 2011, 29, 3466-3473. [CrossRef]

17. Dasanu, C.A. Gemcitabine: Vascular toxicity and prothrombotic potential. Expert Opin. Drug Saf. 2008, 7, 703-716. [CrossRef]

18. Humphreys, B.D.; Sharman, J.P.; Henderson, J.M.; Clark, J.W.; Marks, P.W.; Rennke, H.G.; Zhu, A.X.; Magee, C.C. Gemcitabine-associated thrombotic microangiopathy. Cancer 2004, 100, 2664-2670. [CrossRef]

19. Holstein, A.; Bätge, R.; Egberts, E.H. Gemcitabine induced digital ischaemia and necrosis. Eur. J. Cancer Care (Engl.) 2010, 19, 408-409. [CrossRef]

20. Wachters, F.M.; Van Der Graaf, W.T.; Groen, H.J. Cardiotoxicity in advanced non-small cell lung cancer patients treated with platinum and non-platinum based combinations as first-line treatment. Anticancer Res. 2004, 24, 2079-2083.

21. Sandler, A.B.; Nemunaitis, J.; Denham, C.; von Pawel, J.; Cormier, Y.; Gatzemeier, U.; Mattson, K.; Manegold, C.; Palmer, M.C.; Gregor, A.; et al. Phase III trial of gemcitabine plus cisplatin versus cisplatin alone in patients with locally advanced or metastatic non-small-cell lung cancer. J. Clin. Oncol. 2000, 18, 122-130. [CrossRef] [PubMed]

22. Spigel, D.R.; Hainsworth, J.D.; Shipley, D.L.; Ervin, T.J.; Kohler, P.C.; Lubiner, E.T.; Peyton, J.D.; Waterhouse, D.M.; Burris, H.A., 3rd; Greco, F.A. A Randomized Phase II Trial of Pemetrexed/Gemcitabine/Bevacizumab or Pemetrexed/Carboplatin/Bevacizumab in the First-Line Treatment of Elderly Patients with Advanced Non-small Cell Lung Cancer. J. Thorac. Oncol. 2012, 7, 196-202. [CrossRef]

23. Roca, E.; Bruera, E.; Politi, P.M.; Barugel, M.; Cedaro, L.; Carraro, S.; Chacón, R.D. Vinca alkaloid-induced cardiovascular autonomic neuropathy. Cancer Treat. Rep. 1985, 69, 149-151. [PubMed]

24. Lejonc, J.L.; Vernant, J.P.; Macquin, J.; Castaigne, A. Myocardial infarction following vinblastine treatment. Lancet 1980, 2, 692. [CrossRef]

25. Lapeyre-Mestre, M.; Gregoire, N.; Bugat, R.; Montastruc, J.L. Vinorelbine-related cardiac events: A meta-analysis of randomized clinical trials. Fundam. Clin. Pharmacol. 2004, 18, 97-105. [CrossRef] [PubMed]

26. Clark, J.I.; Kancharla, K.; Qamar, R.; Fisher, S.; Hantel, A.; Panganiban, J.; Millbrandt, L.; Albain, K.S. Pilot study of sequential vinorelbine and cisplatin followed by docetaxel for selected IIIB and stage IV non-small cell lung cancer. Lung Cancer 2001, 34, 271-277. [CrossRef] 
27. Gebbia, V.; Galetta, D.; Caruso, M.; Verderame, F.; Pezzella, G.; Valdesi, M.; Borsellino, N.; Pandolfo, G.; Durini, E.; Rinaldi, M.; et al. Gemcitabine and cisplatin versus vinorelbine and cisplatin versus ifosfamide+gemcitabine followed by vinorelbine and cisplatin versus vinorelbine and cisplatin followed by ifosfamide and gemcitabine in stage IIIB-IV non small cell lung carcinoma: A prospective randomized phase III trial of the Gruppo Oncologico Italia Meridionale. Lung Cancer 2003, 39, 179-189. [PubMed]

28. Liu, L.; Wang, X.W.; Li, L.; Zhang, X.; Zhang, W.D.; Yu, X.J. A randomized comparative trial of three combined regimens containing cisplatin for treatment of advanced non-small cell lung cancer. Ai Zheng 2006, 25, 990-994.

29. Sevelda, P.; Mayerhofer, K.; Obermair, A.; Stolzlechner, J.; Kurz, C. Thrombosis with paclitaxel. Lancet 1994, 343, 727. [CrossRef]

30. Yahalom, J.; Portlock, C.S. Cardiac toxicity. In Cancer Principles E Practice of Oncology; De Vita, V.T., Jr., Lawrence, T.S., Rosenberg, S.A., Eds.; Lippincot Williams \& Wilkins: Philadelphia, PA, USA, 2011; pp. 2360-2367.

31. Rowinsky, E.K.; McGuire, W.P.; Guarnieri, T.; Fisherman, J.S.; Christian, M.C.; Donehower, R.C. Cardiac disturbances during the administration of Taxol. J. Clin. Oncol. 1991, 9, 1704-1712. [CrossRef]

32. Trimble, E.L.; Adams, J.D.; Vena, D.; Hawkins, M.J.; Friedman, M.A.; Fisherman, J.S.; Christian, M.C.; Canetta, R.; Onetto, N.; Hayn, R. Paclitaxel for platinum-refractory ovarian cancer: Results from the first 1000 patients registered to National Cancer Institute Treatment Referral Center 9103. J. Clin. Oncol. 1993, 11, 2405-2410. [CrossRef] [PubMed]

33. Arbuck, S.G.; Strauss, H.; Rowinsky, E.; Christian, M.; Suffness, M.; Adams, J.; Oakes, M.; McGuire, W.; Reed, E.; Gibbs, H.; et al. A reassessment of cardiac toxicity associated with taxol. J. Natl. Cancer Inst. Monogr. 1993, 15, 117-130.

34. Pío-Asín, M.; Segrelles-Bellmunt, G.; Arrondo-Velasco, A.; Sarobe-Carricas, M. Acute myocardial infarction and pemetrexed. Farm. Hosp. 2009, 33, 114-115. [CrossRef]

35. Miyagawa, J.; Higashiyama, S.; Kawata, S.; Inui, Y.; Tamura, S.; Yamamoto, K.; Nishida, M.; Nakamura, T.; Yamashita, S.; Matsuzawa, Y. Localization of heparin-binding EGF-like growth factor in the smooth muscle cells and macrophages of human atherosclerotic plaques. J. Clin. Investig. 1995, 95, 404-411. [CrossRef]

36. Zaborowska-Szmit, M.; Kowalski, D.M.; Piórek, A.; Krzakowski, M.; Szmit, S. A decrease in D-dimer concentration and an occurrence of skin rash as iatrogenic events and complementary predictors of survival in lung cancer patients treated with EGFR tyrosine kinase inhibitors. Pharmacol. Rep. 2016, 68, 1140-1148. [CrossRef]

37. Moore, M.J.; Goldstein, D.; Hamm, J.; Figer, A.; Hecht, J.R.; Gallinger, S.; Au, H.J.; Murawa, P.; Walde, D.; Wolff, R.A.; et al. Erlotinib plus gemcitabine compared with gemcitabine alone in patients with advanced pancreatic cancer: A phase III trial of the National Cancer Institute of Canada Clinical Trials Group. J. Clin. Oncol. 2007, 25, 1960-1966. [CrossRef]

38. Herbst, R.S.; Ansari, R.; Bustin, F.; Flynn, P.; Hart, L.; Otterson, G.A.; Vlahovic, G.; Soh, C.H.; O'Connor, P.; Hainsworth, J. Efficacy of bevacizumab plus erlotinib versus erlotinib alone in advanced non-small-cell lung cancer after failure of standard first-line chemotherapy (BeTa): A double-blind, placebo-controlled, phase 3 trial. Lancet 2011, 377, 1846-1854. [CrossRef]

39. Kanazawa, S.; Yamaguchi, K.; Kinoshita, Y.; Muramatsu, M.; Komiyama, Y.; Nomura, S. Gefitinib affects functions of platelets and blood vessels via changes in prostanoids balance. Clin. Appl. Thromb. Hemost. 2005, 11, 429-434. [CrossRef]

40. Kanazawa, S.; Yamaguchi, K.; Kinoshita, Y.; Muramatsu, M.; Komiyama, Y.; Nomura, S. Aspirin reduces adverse effects of gefitinib. Anticancer Drugs 2006, 17, 423-427. [CrossRef]

41. Yamaguchi, K.; Kanazawa, S.; Kinoshita, Y.; Muramatsu, M.; Nomura, S. Acute myocardial infarction with lung cancer during treatment with gefitinib: The possibility of gefitinib-induced thrombosis. Pathophysiol. Haemost. Thromb. 2005, 34, 48-50. [CrossRef]

42. Lynch, D.R., Jr.; Kickler, T.S.; Rade, J.J. Recurrent myocardial infarction associated with gefitinib therapy. J. Thromb. Thrombolysis 2011, 32, 120-124. [CrossRef] [PubMed]

43. Solca, F.; Dahl, G.; Zoephel, A.; Bader, G.; Sanderson, M.; Klein, C.; Kraemer, O.; Himmelsbach, F.; Haaksma, E.; Adolf, G.R. Target binding properties and cellular activity of afatinib (BIBW 2992), an irreversible ErbB family blocker. J. Pharmacol. Exp. Ther. 2012, 343, 342-350. [CrossRef] 
44. Ewer, M.S.; Patel, K.; O’Brien, D.; Lorence, R.M. Cardiac safety of afatinib: A review of data from clinical trials. Cardio-Oncology 2015, 1, 3. [CrossRef]

45. Anand, K.; Ensor, J.; Trachtenberg, B.; Bernicker, E.H. Osimertinib-induced cardiotoxicity: A retrospective review of the FDA adverse events reporting system (FAERS). J. Am. Coll. Cardiol. Cardio Oncol. 2019, 1, $172-178$.

46. Mok, T.S.; Wu, Y.-L.; Ahn, M.-J.; Garassino, M.C.; Kim, H.R.; Ramalingam, S.S.; Shepherd, F.A.; He, Y.; Akamatsu, H.; Theelen, W.S.; et al. Osimertinib or Platinum-Pemetrexed in EGFR T790M-Positive Lung Cancer. N. Engl. J. Med. 2017, 376, 629-640. [CrossRef]

47. Soria, J.C.; Ohe, Y.; Vansteenkiste, J.; Reungwetwattana, T.; Chewaskulyong, B.; Lee, K.H.; Dechaphunkul, A.; Imamura, F.; Nogami, N.; Kurata, T.; et al. Osimertinib in Untreated EGFR-Mutated Advanced Non-Small-Cell Lung Cancer. N. Engl. J. Med. 2018, 378, 113-125. [CrossRef] [PubMed]

48. Yi, L.; Fan, J.; Qian, R.; Luo, P.; Zhang, J. Efficacy and safety of osimertinib in treating EGFR-mutated advanced NSCLC: A meta-analysis. Int. J. Cancer 2019, 145, 284-294. [CrossRef] [PubMed]

49. Chaft, J.E.; Oxnard, G.R.; Sima, C.S.; Kris, M.G.; Miller, V.A.; Riely, G.J. Disease flare after tyrosine kinase inhibitor discontinuation in patients with EGFR-mutant lung cancer and acquired resistance to erlotinib or gefitinib: Implications for clinical trial design. Clin. Cancer Res. 2011, 17, 6298-6303. [CrossRef]

50. Schiefer, M.; Hendriks, L.E.L.; Dinh, T.; Lalji, U.; Dingemans, A.C. Current perspective: Osimertinib-induced QT prolongation: New drugs with new side-effects need careful patient monitoring. Eur. J. Cancer. 2018, 91, 9298. [CrossRef] [PubMed]

51. Lu, Z.; Wu, C.Y.; Jiang, Y.P.; Ballou, L.M.; Clausen, C.; Cohen, I.S.; Lin, R.Z. Suppression of phosphoinositide 3-kinase signaling and alteration of multiple ion currents in drug-induced long QT syndrome. Sci. Transl. Med. 2012, 4, 131ra50. [CrossRef]

52. Oyakawa, T.; Nakashima, K.; Naito, T. Cardiac Dysfunction Caused by Osimertinib. J. Thorac. Oncol. 2017, 12, e159-e160. [CrossRef] [PubMed]

53. Watanabe, H.; Ichihara, E.; Kano, H.; Ninomiya, K.; Tanimoto, M.; Kiura, K. Congestive Heart Failure During Osimertinib Treatment for Epidermal Growth Factor Receptor (EGFR)-mutant Non-small Cell Lung Cancer (NSCLC). Intern. Med. 2017, 56, 2195-2197. [CrossRef] [PubMed]

54. Cross, D.A.; Ashton, S.E.; Ghiorghiu, S.; Eberlein, C.; Nebhan, C.A.; Spitzler, P.J.; Orme, J.P.; Finlay, M.R.; Ward, R.A.; Mellor, M.J.; et al. AZD9291, an irreversible EGFR TKI, overcomes T790M-mediated resistance to EGFR inhibitors in lung cancer. Cancer Discov. 2014, 4, 1046-1061. [CrossRef] [PubMed]

55. Zer, A.; Moskovitz, M.; Hwang, D.M.; Hershko-Klement, A.; Fridel, L.; Korpanty, G.J.; Dudnik, E.; Peled, N.; Shochat, T.; Leighl, N.B.; et al. ALK-Rearranged Non-Small-Cell Lung Cancer Is Associated With a High Rate of Venous Thromboembolism. Clin. Lung Cancer 2017, 18, 156-161. [CrossRef] [PubMed]

56. Chiari, R.; Ricciuti, B.; Landi, L.; Morelli, A.M.; Delmonte, A.; Spitaleri, G.; Cortinovis, D.L.; Lamberti, G.; Facchinetti, F.; Pilotto, S.; et al. ROS1-rearranged Non-small-cell Lung Cancer is Associated With a High Rate of Venous Thromboembolism: Analysis From a Phase II, Prospective, Multicenter, Two-arms Trial (METROS). Clin. Lung Cancer 2020, 21, 15-20. [CrossRef] [PubMed]

57. Tartarone, A.; Gallucci, G.; Lazzari, C.; Lerose, R.; Lombardi, L.; Aieta, M. Crizotinib-induced cardiotoxicity: The importance of a proactive monitoring and management. Future Oncol. 2015, 11, 2043-2048. [CrossRef]

58. Zhang, Z.; Huang, T.-Q.; Nepliouev, I.; Zhang, H.; Barnett, A.S.; Rosenberg, P.B.; Ou, S.I.; Stiber, J.A. Crizotinib Inhibits Hyperpolarization-activated cyclic nucleotide-gated channel 4 activity. Cardiooncology 2017, 3, 1. [CrossRef]

59. Weickhardt, A.J.; Rothman, M.S.; Salian-Mehta, S.; Kiseljak-Vassiliades, K.; Oton, A.B.; Doebele, R.C.; Wierman, M.E.; Camidge, D.R. Rapid-onset hypogonadism secondary to crizotinib use in men with metastatic non small cell lung cancer. Cancer 2012, 118, 5302-5309. [CrossRef]

60. Ou, S.H.; Tong, W.P.; Azada, M.; Siwak-Tapp, C.; Dy, J.; Stiber, J.A. Heart rate decrease during crizotinib treatment and potential correlation to clinical response. Cancer 2013, 119, 1969-1975. [CrossRef]

61. Shaw, A.T.; Kim, D.W.; Nakagawa, K.; Seto, T.; Crinó, L.; Ahn, M.J.; De Pas, T.; Besse, B.; Solomon, B.J.; Blackhall, F.; et al. Crizotinib versus chemotherapy in advanced ALK-positive lung cancer. N. Engl. J. Med. 2013, 368, 2385-2394. [CrossRef]

62. Solomon, B.J.; Mok, T.; Kim, D.W.; Wu, Y.L.; Nakagawa, K.; Mekhail, T.; Felip, E.; Cappuzzo, F.; Paolini, J.; Usari, T.; et al. First-line crizotinib versus chemotherapy in ALK-positive lung cancer. N. Engl. J. Med. 2014, 371, 2167-2177. [CrossRef] [PubMed] 
63. Pérez-Callejo, D.; Torrente, M.; Brenes, M.A.; Núñez, B.; Provencio, M. Lungcancer as a cardiotoxicstate: A review. Med. Oncol. 2017, 34, 159. [CrossRef] [PubMed]

64. Morcos, P.N.; Bogman, K.; Hubeaux, S.; Sturm-Pellanda, C.; Ruf, T.; Bordogna, W.; Golding, S.; Zeaiter, A.; Abt, M.; Balas, B. Effect of alectinib on cardiac electrophysiology: Results from intensive electrocardiogram monitoring from the pivotal phase IINP28761 and NP28673 studies. Cancer Chemother. Pharmacol. 2017, 79, 559-568. [CrossRef]

65. Gettinger, S.N.; Bazhenova, L.A.; Langer, C.J.; Salgia, R.; Gold, K.A.; Rosell, R.; Shaw, A.T.; Weiss, G.J.; Tugnait, M.; Narasimhan, N.I.; et al. Activity and safety of brigatinib in ALK-rearranged non-small-cell lung cancer and other malignancies: A single-arm, open-label, phase 1/2 trial. Lancet Oncol. 2016, 17, 1683-1696. [CrossRef]

66. Izzedine, H.; Ederhy, S.; Goldwasser, F.; Soria, J.C.; Milano, G.; Cohen, A.; Khayat, D.; Spano, J.P. Management of hypertension in angiogenesis inhibitor-treated patients. Ann. Oncol. 2009, 20, 807-815. [CrossRef] [PubMed]

67. Pande, A.; Lombardo, J.; Spangenthal, E.; Javle, M. Hypertension secondary to anti-angiogenic therapy: Experience with bevacizumab. Anticancer Res. 2007, 27, 3465-3470.

68. Sandler, A.B.; Johnson, D.H.; Herbst, R.S. Anti-vascular endothelial growth factor monoclonals in non-small cell lung cancer. Clin. Cancer Res. 2004, 10, 4258s-4262s. [CrossRef]

69. Yang, J.C.; Haworth, L.; Sherry, R.M.; Hwu, P.; Schwartzentruber, D.J.; Topalian, S.L.; Steinberg, S.M.; Chen, H.X.; Rosenberg, S.A. A randomized trial of bevacizumab, an anti-vascular endothelial growth factor antibody, for metastatic renal cancer. N. Engl. J. Med. 2003, 349, 427-434. [CrossRef]

70. Miller, K.D.; Chap, L.I.; Holmes, F.A.; Cobleigh, M.A.; Marcom, P.K.; Fehrenbacher, L.; Dickler, M.; Overmoyer, B.A.; Reimann, J.D.; Sing, A.P.; et al. Randomized phase III trial of capecitabine compared with bevacizumab plus capecitabine in patients with previously treated metastatic breast cancer. J. Clin. Oncol. 2005, 23, 792-799. [CrossRef]

71. Johnson, D.H.; Fehrenbacher, L.; Novotny, W.F.; Herbst, R.S.; Nemunaitis, J.J.; Jablons, D.M.; Langer, C.J.; DeVore, R.F., 3rd; Gaudreault, J.; Damico, L.A.; et al. Randomized phase II trial comparing bevacizumab plus carboplatin and paclitaxel with carboplatin and paclitaxel alone in previously untreated locally advanced or metastatic non-small-cell lung cancer. J. Clin. Oncol. 2004, 22, 2184-2191. [CrossRef]

72. Dahlberg, S.E.; Sandler, A.B.; Brahmer, J.R.; Schiller, J.H.; Johnson, D.H. Clinical course of advanced non-small-cell lung cancer patients experiencing hypertension during treatment with bevacizumab in combination with carboplatin and paclitaxel on ECOG 4599. J. Clin. Oncol. 2010, 28, 949-954. [CrossRef] [PubMed]

73. Zhu, X.; Wu, S.; Dahut, W.L.; Parikh, C.R. Risks of proteinuria and hypertension with bevacizumab, an antibody against vascular endothelial growth factor: Systematic review and meta-analysis. Am. J. Kidney Dis. 2007, 49, 186-193. [CrossRef] [PubMed]

74. Gressett, S.M.; Shah, S.R. Intricacies of bevacizumab-induced toxicities and their management. Ann. Pharm. 2009, 43, 490-501. [CrossRef] [PubMed]

75. Levy, B.I.; Ambrosio, G.; Pries, A.R.; Struijker-Boudier, H.A. Microcirculation in hypertension: A new target for treatment? Circulation 2001, 104, 735-740. [CrossRef]

76. Cohen, M.H.; Gootenberg, J.; Keegan, P.; Pazdur, R. FDA drug approval summary: Bevacizumab (Avastin) plus Carboplatin and Paclitaxel as first-line treatment of advanced/metastatic recurrent nonsquamous non-small cell lung cancer. Oncologist 2007, 12, 713-718. [CrossRef]

77. Chen, M.H.; Kerkela, R.; Force, T. Mechanisms of cardiac dysfunction associated with tyrosine kinase inhibitor cancer therapeutics. Circulation 2008, 118, 84-95. [CrossRef]

78. Hawkes, E.A.; Okines, A.F.; Plummer, C.; Cunningham, D. Cardiotoxicity in patients treated with bevacizumab is potentially reversible. J. Clin. Oncol. 2011, 29, e560-e562. [CrossRef]

79. Choueiri, T.K.; Mayer, E.L.; Je, Y.; Rosenberg, J.E.; Nguyen, P.L.; Azzi, G.R.; Bellmunt, J.; Burstein, H.J.; Schutz, F.A. Congestive heart failure risk in patients with breast cancer treated with bevacizumab. J. Clin. Oncol. 2011, 29, 632-638. [CrossRef]

80. Miura, S.; Maemondo, M.; Iwashima, A.; Harada, T.; Sugawara, S.; Kobayashi, K.; Inoue, A.; Nakagawa, T.; Takiguchi, Y.; Watanabe, H.; et al. A phase II study of carboplatin plus weekly paclitaxel with bevacizumab for elderly patients with non-squamous non-small-cell lung cancer (NEJ016). Investig. New Drugs 2017, 35, 227-234. [CrossRef] 
81. Scappaticci, F.A.; Skillings, J.R.; Holden, S.N.; Gerber, H.P.; Miller, K.; Kabbinavar, F.; Bergsland, E.; Ngai, J.; Holmgren, E.; Wang, J.; et al. Arterial thromboembolic events in patients with metastatic carcinoma treated with chemotherapy and bevacizumab. J. Natl. Cancer Inst. 2007, 99, 1232-1239. [CrossRef]

82. Kamba, T.; McDonald, D.M. Mechanisms of adverse effects of anti-VEGF therapy for cancer. Br. J. Cancer 2007, 96, 1788-1795. [CrossRef] [PubMed]

83. Totzeck, M.; Mincu, R.I.; Rassaf, T. Cardiovascular Adverse Events in Patients with Cancer Treated With Bevacizumab: A Meta-Analysis of More Than 20,000 Patients. J. Am. Heart Assoc. 2017, 6, e006278. [CrossRef] [PubMed]

84. Reck, M.; von, P.J.; Zatloukal, P.; Ramlau, R.; Gorbounova, V.; Hirsh, V.; Leighl, N.; Mezger, J.; Archer, V.; Moore, N.; et al. Phase III trial of cisplatin plus gemcitabine with either placebo or bevacizumab as first-line therapy for nonsquamous non-small-cell lung cancer: AVAil. J. Clin. Oncol. 2009, 27, 1227-1234. [CrossRef] [PubMed]

85. Noth, I.; Wijsenbeek, M.; Kolb, M.; Bonella, F.; Moros, L.; Wachtlin, D.; Corte, T.J. Cardiovascular safety of nintedanib in subgroups by cardiovascular risk at baseline in the TOMORROW and INPULSIS trials. Eur. Respir. J. 2019, 54, 1801797. [CrossRef] [PubMed]

86. Reck, M.; Kaiser, R.; Mellemgaard, A.; Douillard, J.Y.; Orlov, S.; Krzakowski, M.; von Pawel, J.; Gottfried, M.; Bondarenko, I.; Liao, M.; et al. Docetaxel plus nintedanib versus docetaxel plus placebo in patients with previously treated non-small-cell lung cancer (LUME-Lung 1): A phase 3, double-blind, randomised controlled trial. Lancet Oncol. 2014, 15, 143-155. [CrossRef]

87. Hanna, N.H.; Kaiser, R.; Sullivan, R.N.; Aren, O.R.; Ahn, M.J.; Tiangco, B.; Voccia, I.; Pawel, J.V.; Kovcin, V.; Agulnik, J.; et al. Nintedanib plus pemetrexed versus placebo plus pemetrexed in patients with relapsed or refractory, advanced non-small cell lung cancer (LUME-Lung 2): A randomized, double-blind, phase III trial. Lung Cancer 2016, 102, 65-73. [CrossRef]

88. Manzo, A.; Carillio, G.; Montanino, A.; Costanzo, R.; Sandomenico, C.; Rocco, G.; Morabito, A. Focus on Nintedanib in NSCLC and Other Tumors. Front. Med. (Lausanne) 2016, 3, 68. [CrossRef]

89. Reck, M.; Mellemgaard, A.; von Pawel, J.; Gottfried, M.; Bondarenko, I.; Cheng, Y.; Zarogoulidis, K.; Luft, A.; Bennouna, J.; Barrueco, J.; et al. Anti-angiogenic-specific adverse events in patients with non-small cell lung cancer treated with nintedanib and docetaxel. Lung Cancer 2015, 90, 267-273. [CrossRef]

90. Lyon, A.R.; Yousaf, N.; Battisti, N.M.L.; Moslehi, J.; Larkin, J. Immune checkpoint inhibitors and cardiovascular toxicity. Lancet Oncol. 2018, 19, e447-e458. [CrossRef]

91. Gandhi, L.; Rodríguez-Abreu, D.; Gadgeel, S.; Esteban, E.; Felip, E.; De Angleis, F.; Domine, M.; Clingan, P.; Hochmair, M.J.; Powell, S.F.; et al. Pembrolizumab plus Chemotherapy in Metastatic Non-Small-Cell Lung Cancer. N. Engl. J. Med. 2018, 378, 2078-2092. [CrossRef]

92. Paz-Ares, L.; Luft, A.; Vicente, D.; Tafreshi, A.; Gümüş, M.; Mazières, J.; Hermes, B.; ÇayŞenler, F.; Csőszi, T.; Fülöp, A.; et al. Pembrolizumab plus Chemotherapy for Squamous Non-Small-Cell Lung Cancer. N. Engl. J. Med. 2018, 379, 2040-2051. [CrossRef]

93. Antonia, S.J.; Villegas, A.; Daniel, D.; Vicente, D.; Murakami, S.; Hui, R.; Yokoi, T.; Chiappori, A.; Lee, K.H.; de Wit, M.; et al. Durvalumab after Chemoradiotherapy in Stage III Non-Small-Cell Lung Cancer. N. Engl. J. Med. 2017, 377, 1919-1929. [CrossRef]

94. Amiri-Kordestani, L.; Moslehi, J.; Cheng, J.; Tang, S.; Schroeder, R.; Sridhara, R.; Karg, K.; Connolly, J.; Beaver, J.A.; Blumenthal, G.M.; et al. Cardiovascular adverse events in immune checkpoint inhibitor clinical trials: A U.S. Food and Drug Administration pooled analysis. J. Clin. Oncol. 2018, 36, 3009. [CrossRef]

95. Ganatra, S.; Neilan, T.G. Immune checkpoint inhibitor-associated myocarditis. Oncologist 2018, 23, 879-886. [CrossRef]

96. Kanjanapan, Y.; Day, D.; Butler, M.O.; Wang, L.; Joshua, A.M.; Hogg, D.; Leighl, N.B.; Razak, A.R.A.; Hansen, A.R.; Boujos, S.; et al. Delayed immune-related adverse events in assessment for dose-limiting toxicity in early phase immunotherapy trials. Eur. J. Cancer 2019, 107, 1-7. [CrossRef]

97. Dolladille, C.; Ederhy, S.; Allouche, S.; Dupas, Q.; Gervais, R.; Madelaine, J.; Sassier, M.; Plane, A.F.; Comoz, F.; Cohen, A.A.; et al. Late cardiac adverse events in patients with cancer treated with immune checkpoint inhibitors. J. Immunother. Cancer 2020, 8, e000261. [CrossRef]

98. Chitturi, K.R.; Xu, J.; Araujo-Gutierrez, R.; Bhimaraj, A.; Guha, A.; Hussain, I.; Kassi, M.; Bernicker, E.H.; Trachtenberg, B.H. Immune checkpoint inhibitor-related adverse cardiovascular events in patients with lung cancer. J. Am. Coll. Cardiol. Cardio Oncol. 2019, 1, 182-192. [CrossRef] 
99. Escudier, M.; Cautela, J.; Malissen, N.; Ancedy, Y.; Orabona, M.; Pinto, J.; Monestier, S.; Grob, J.J.; Scemama, U.; Jacquier, A.; et al. Clinical Features, Management, and Outcomes of Immune Checkpoint Inhibitor-Related Cardiotoxicity. Circulation 2017, 136, 2085-2087. [CrossRef]

100. Mahmood, S.S.; Fradley, M.G.; Cohen, J.V.; Nohria, A.; Reynolds, K.L.; Heinzerling, L.M.; Sullivan, R.J.; Damrongwatanasuk, R.; Chen, C.L.; Gupta, D.; et al. Myocarditis in Patients Treated With Immune Checkpoint Inhibitors. J. Am. Coll. Cardiol. 2018, 71, 1755-1764. [CrossRef]

101. Spallarossa, P.; Tini, G.; Sarocchi, M.; Arboscello, E.; Grossi, F.; Queirolo, P.; Zoppoli, G.; Ameri, P. Identification and Management of Immune Checkpoint Inhibitor-Related Myocarditis: Use Troponin Wisely. J. Clin. Oncol. 2019, 37, 2201-2205. [CrossRef]

102. Bar, J.; Markel, G.; Gottfried, T.; Percik, R.; Leibowitz-Amit, R.; Berger, R.; Golan, T.; Daher, S.; Taliansky, A.; Dudnik, E.; et al. Acute vascular events as a possibly related adverse event of immunotherapy: A single-institute retrospective study. Eur. J. Cancer 2019, 120, 122-131. [CrossRef]

103. Nesfeder, J.; Elsensohn, A.N.; Thind, M.; Lennon, J.; Domsky, S. Pericardial effusion with tamponade physiology induced by nivolumab. Int. J. Cardiol. 2016, 222, 613-614. [CrossRef]

104. Vittorio, A.; Sharma, R.; Siejka, D.; Bhattarai, K.; Hardikar, A. Recurrent Pericardial Effusion While Receiving Nivolumab for Metastatic Lung Adenocarcinoma: Case Report and Review of the Literature. Clin. Lung Cancer 2018, 19, e717-e720. [CrossRef]

105. Kolla, B.C.; Patel, M.R. Recurrent pleural effusions and cardiac tamponade as possible manifestations of pseudoprogression associated with nivolumab therapy-A report of two cases. J. Immunother. Cancer 2016, 4, 80. [CrossRef]

106. Palaskas, N.; Morgan, J.; Daigle, T.; Banchs, J.; Durand, J.B.; Hong, D.; Naing, A.; Le, H.; Hassan, S.A.; Karimzad, K.; et al. Targeted Cancer Therapies with Pericardial Effusions Requiring Pericardiocentesis Focusing on Immune Checkpoint Inhibitors. Am. J. Cardiol. 2019, 123, 1351-1357. [CrossRef]

107. Hu, Y.B.; Zhang, Q.; Li, H.J.; Michot, J.M.; Liu, H.B.; Zhan, P.; Lv, T.F.; Song, Y.; Written on Behalf of the AME Academic Lung Cancer Cooperation Group. Evaluation of rare but severe immune related adverse effects in PD-1 and PD-L1 inhibitors in non-small cell lung cancer: A meta-analysis. Transl. Lung Cancer Res. 2017, 6, S8-S20. [CrossRef]

108. Wang, Y.; Zhou, S.; Yang, F.; Qi, X.; Wang, X.; Guan, X.; Shen, C.; Duma, N.; Vera Aguilera, J.; Chintakuntlawar, A.; et al. Treatment-Related Adverse Events of PD-1 and PD-L1 Inhibitors in Clinical Trials: A Systematic Review and Meta-analysis. JAMA Oncol. 2019, 5, 1008-1019. [CrossRef]

109. Master, S.R.; Robinson, A.; Mills, G.M.; Mansour, R.P. Cardiovascular complications of immune checkpoint inhibitor therapy. J. Clin. Oncol. 2019, 37, 2568. [CrossRef]

110. Bonaca, M.P.; Olenchock, B.A.; Salem, J.E.; Wiviott, S.D.; Ederhy, S.; Cohen, A.; Stewart, G.C.; Choueiri, T.K.; Di Carli, M.; Allenbach, Y.; et al. Myocarditis in the Setting of Cancer Therapeutics: Proposed Case Definitions for Emerging Clinical Syndromes in Cardio-Oncology. Circulation 2019, 140, 80-91. [CrossRef]

111. Darocha, S.; Wilk, M.; Walaszkowska-Czyż, A.; Kepski, J.; Mańczak, R.; Kurzyna, M.; Torbicki, A.; Szmit, S. Determinants of Survival After Emergency Intrapericardial Cisplatin Treatment in Cancer Patients with Recurrent Hemodynamic Instability After Pericardiocentesis. In Vivo 2018, 32, 373-379.

112. Armenian, S.H.; Lacchetti, C.; Barac, A.; Carver, J.; Constine, L.S.; Denduluri, N.; Dent, S.; Douglas, P.S.; Durand, J.B.; Ewer, M.; et al. Prevention and Monitoring of Cardiac Dysfunction in Survivors of Adult Cancers: American Society of Clinical Oncology Clinical Practice Guideline. J. Clin. Oncol. 2017, 35, 893-911. [CrossRef]

113. Curigliano, G.; Lenihan, D.; Fradley, M.; Ganatra, S.; Barac, A.; Blaes, A.; Herrmann, J.; Porter, C.; Lyon, A.R.; Lancellotti, P.; et al. Management of cardiac disease in cancer patients throughout oncological treatment: ESMO consensus recommendations. Ann. Oncol. 2020, 31, 171-190. [CrossRef]

(C) 2020 by the authors. Licensee MDPI, Basel, Switzerland. This article is an open access article distributed under the terms and conditions of the Creative Commons Attribution (CC BY) license (http://creativecommons.org/licenses/by/4.0/). 